\title{
Comparative effectiveness of teriflunomide vs dimethyl fumarate in multiple sclerosis
}

\author{
David-Axel Laplaud, MD, PhD, Romain Casey, PhD, Laetitia Barbin, PhD, Marc Debouverie, MD, PhD, Jérôme De Sèze, MD, PhD, \\ David Brassat, MD, PhD, Sandrine Wiertlewski, MD, Bruno Brochet, MD, PhD, Jean Pelletier, MD, PhD, \\ Patrick Vermersch, MD, PhD, Gilles Edan, MD, Christine Lebrun-Frenay, MD, Pierre Clavelou, MD, PhD, Eric Thouvenot, MD, PhD, \\ Jean-Philippe Camdessanché, MD, PhD, Ayman Tourbah, MD, PhD, Bruno Stankoff, MD, PhD, Abdullatif Al Khedr, MD, \\ Philippe Cabre, MD, PhD, Catherine Lubetzki, MD, PhD, Caroline Papeix, MD, Eric Berger, MD, Olivier Heinzlef, MD, \\ Thomas Debroucker, MD, Thibault Moreau, MD, PhD, Olivier Gout, MD, Bertrand Bourre, MD, Abir Wahab, MD, \\ Pierre Labauge, MD, PhD, Laurent Magy, MD, PhD, Gilles Defer, MD, Anne-Marie Guennoc, MD, Nicolas Maubeuge, MD, \\ Céline Labeyrie, MD, Ivania Patry, MD, Chantal Nifle, MD, Olivier Casez, MD, Laure Michel, MD, PhD, Fabien Rollot, MSc, \\ Emmanuelle Leray, PhD, Sandra Vukusic, MD, PhD, and Yohann Foucher, PhD, on behalf of the SFSEP and OFSEP groups
}

Neurology ${ }^{\circledR}$ 2019;93:e635-e646. doi:10.1212/WNL.0000000000007938

\section{Abstract}

\section{Objective}

In this study, we compared the effectiveness of teriflunomide (TRF) and dimethyl fumarate (DMF) on both clinical and MRI outcomes in patients followed prospectively in the Observatoire Français de la Sclérose en Plaques.

\section{Methods}

A total of 1,770 patients with relapsing-remitting multiple sclerosis (RRMS) (713 on TRF and 1,057 on DMF) with an available baseline brain MRI were included in intention to treat. The 1- and 2-year postinitiation outcomes were relapses, increase of T2 lesions, increase in Expanded Disability Status Scale score, and reason for treatment discontinuation. Propensity scores (inverse probability weighting) and logistic regressions were estimated.

\section{Results}

The confounder-adjusted proportions of patients were similar in TRF- compared to DMF-treated patients for relapses and disability progression after 1 and 2 years. However, the adjusted proportion of patients with at least one new T2 lesion after 2 years was lower in DMF compared to TRF (60.8\% vs $72.2 \%$, odds ratio [OR] $0.60, p<0.001)$. Analyses of reasons for treatment withdrawal showed that lack of effectiveness was reported for $8.5 \%$ of DMF-treated patients vs $14.5 \%$ of TRF-treated patients (OR 0.54, $p<0.001$ ), while adverse events accounted for $16 \%$ of TRF-treated patients and $21 \%$ of DMF-treated patients after 2 years (OR 1.39, $p<0.001$ ).

\section{Conclusions}

After 2 years of treatment, we found similar effectiveness of DMF and TRF in terms of clinical outcomes, but with better MRI-based outcomes for DMF-treated patients, resulting in a lower rate of treatment discontinuation due to lack of effectiveness.

\section{Classification of evidence}

This study provides Class III evidence that for patients with RRMS, TRF and DMF have similar clinical effectiveness after 2 years of treatment.

\author{
Correspondence \\ Dr. Laplaud \\ david.laplaud@ \\ univ-nantes.fr
}

RELATED ARTICLE

\section{Editorial}

Harnessing real-world data to inform treatment decisions in multiple sclerosis

Page 285

\section{MORE ONLINE}

$\rightarrow$ Class of Evidence

Criteria for rating therapeutic and diagnostic studies

NPub.org/coe 


\section{Glossary}

CI = confidence interval; DMF = dimethyl fumarate; DMT = disease-modifying therapy; EDSS = Expanded Disability Status Scale; IPW = inverse probability weighting; $\mathbf{M S}=$ multiple sclerosis; NEDA = no evidence of disease activity; OFSEP = Observatoire Français de la Sclérose En Plaques; OR = odds ratio; $\mathbf{R C T}=$ randomized controlled trial; RRMS = relapsingremitting multiple sclerosis; $\mathbf{T R F}=$ teriflunomide.

Over the last 20 years, considerable progress has been achieved with therapeutic innovations reducing the incidence of relapses in multiple sclerosis (MS). These treatments target the immune system and are intended to slow the natural evolution of the disease. Recently, 2 new oral molecules have been marketed for MS: teriflunomide (TRF) and dimethyl fumarate (DMF). Both treatments have demonstrated their efficacy in relapsing-remitting MS (RRMS) to reduce annualized relapse rate, disability accumulation, and T2 lesion accrual at 2 years compared with placebo. ${ }^{1-7}$

Knowing which of the 2 treatments is more effective or better tolerated is of high importance for neurologists and their patients. Recent observational studies have reported inconsistent results regarding clinical MS activity at 1 year (annualized relapse rate, time to first relapse) but none has compared clinical efficacy, MRI disease activity, and treatment withdrawals at 1 and 2 years in a large population of patients. ${ }^{8-12}$ Such a study has the advantage of being more representative of real-life practices and effects, even if the treated patients are often noncomparable directly due to indication biases. In this context, taking advantage of the French Multiple Sclerosis Registry (Observatoire Français de la Sclérose En Plaques [OFSEP]), we propose to compare the real-life effectiveness and tolerance of DMF and TRF, using weighted propensity scores to deal with possible confounders.

\section{Methods}

\section{Classification of evidence}

This observational study provides Class III evidence that the proportion of patients with at least one relapse is similar after 1 year of treatment with TRF or DMF in patients with RRMS.

\section{The OFSEP cohort}

OFSEP is a network of French neurologists, mainly from 34 MS centers. Data are collected prospectively during each visit or hospitalization on a standardized clinical form and collected in the European Database for Multiple Sclerosis (EDMUS) software. ${ }^{13}$ Individual case reports include identification and demographic data, medical history, biological, electrophysiologic, and MRI data, treatments, as well as key episodes in MS course (date of relapses, date of secondary progression, dates and level of disability progression). Data are checked for consistency using automatic controls in the software.

\section{Standard protocol approvals, registrations, and patient consents}

All patients included in the OFSEP cohort sign an informed consent to have their medical data collected in routine practice used after anonymization and aggregation for research purposes. The reasons behind treatment withdrawal were prospectively collected in the OFSEP cohort, as the neurologist following the patient had to fill in a short questionnaire selecting different reasons for treatment discontinuation (local, general, or biological intolerance, lack of effectiveness, pregnancy, desire to become pregnant, other). Local intolerance referred for example to cutaneous adverse event with injectable treatments, general intolerance referred for example to fever or myalgia in case of flu-like syndrome, and biological intolerance referred to a biological abnormality observed under treatment like for example elevated liver enzymes. Serious adverse events are specifically enclosed in the form. The initial folder has received the agreement of the Comité Consultatif sur le Traitement de l'Information en Matière de Recherche (CCTIRS) (December 18, 2013, reference 13.591bis, and June 27, 2014) and the Commission Nationale de l'Informatique et des Libertés (CNIL) (May 6, 2014, request 914.066, authorization decisions DR-2014-110 and DR-2014-327). The OFSEP cohort has been registered in clinicaltrials.gov (NCT02889965). For the current study, data were extracted on December 15, 2017. The study was registered in clinicaltrials.gov (NCT03302442).

\section{Patients}

All adults with RRMS defined by the 2010 revised MacDonald criteria ${ }^{14}$ and followed in one of the 34 MS centers participating in the OFSEP network were included in the study. The following inclusion criteria were defined: patients with RRMS nonopposed to participation to the study, aged from 18 to 65 years, treatment-naive or previously treated with other firstline disease-modifying therapies (DMTs) (interferons or glatiramer acetate), who initiated either TRF or DMF between May 1, 2014, and January 1, 2016 (as both treatments were available at these dates, avoiding any bias related to positivity assumption), with an available MRI scan and Expanded Disability Status Scale (EDSS) assessment within the 6 months before treatment initiation, and with an EDSS score ranging from 0 to 5.5 at treatment initiation. Patients with prior second-line treatment were not included (natalizumab, fingolimod, cyclophosphamide, mitoxantrone, alemtuzumab, or rituximab). A total of 1,916 patients with nonavailable brain or spine MRI or EDSS evaluation in the previous 6 months before initiating DMF or TRF were not included as these 
variables were a priori considered as possible confounders for the comparison of the 2 treatments. Therefore, the study was performed with intention to treat, including the patients who actually started the treatment.

\section{Outcomes}

\section{Study schedule}

The baseline was the DMF or TRF initiation date. Since our study was based on data from real-life practice, MRI and EDSS evaluations were not scheduled. Therefore, we defined 2 periods. First, we considered data collected between 6 months preinitiation and 3 months postinitiation as baseline MRI or EDSS. In case of multiple visits within this period, we retained the closest visit from the beginning of the treatment. Second, we considered data collected between 9 and 18 months postinitiation as 1-year MRI or EDSS. In case of multiple visits within this period, we selected the closest visit from the first postinitiation anniversary.

\section{Outcomes}

The main outcome was the proportion of patients with at least 1 relapse at 1 year postinitiation. Relapses were defined by any new or recurrent exacerbation of neurologic symptoms without fever that lasted for at least 24 hours. Five secondary endpoints were also analyzed after 1 year: the proportion of patients with an increased EDSS score compared to baseline, the proportion of patients with at least one new T2 lesion, the proportion of patients with no evidence of disease activity (NEDA3) (i.e., no new T2 lesion, no increase in the EDSS, and no relapse), ${ }^{15}$ the proportion of treatment discontinuation due to inefficacy, and the proportion of treatment discontinuation due to side effects.

We also reported the 6 previous outcomes at 2 years postinitiation. We considered data collected within 21 and 30 months postinitiation as 2-year MRI or EDSS. In case of multiple visits within this period, we retained the closest visit from the second anniversary postinitiation.

\section{Statistical analyses}

Baseline comparisons were performed using Student $t$ tests or $\chi^{2}$ tests for quantitative or categorical variables, respectively. In order to deal with confounders, we chose a propensity score-based approach-the inverse probability weighting (IPW) estimator with stabilized weights ${ }^{16}$ - to estimate average treatment effect. Multivariable logistic regressions were used to obtain the weights. Calibration was evaluated by plotting observed vs predicted probability of receiving DMF instead of TRF (figures e-1 to e-12, doi.org/10.5061/dryad. 60tv071). Regarding goodness-of-fit for each model, we did not further explore the violation of the log-linearity assumption for continuous explanatory variables. Variables associated with the outcomes were considered as possible confounding factors $(p<$ 0.20 ), in accordance with recent recommendations. ${ }^{17,18}$ One propensity score model was therefore constructed for each outcome (table 1). Compared to the consideration of the true confounders subvector, that is, the variables associated with both treatment allocation and outcome, our strategy for variable selection in the propensity score models may improve estimation precision without adding bias. ${ }^{19}$ We did not include variables only associated with treatment allocation, since it has been demonstrated that such instrumental variables may increase the bias of the effect estimation. ${ }^{20}$ We checked that these possible confounding factors were associated with standardized differences lower than $10 \%$ in the corresponding pseudosamples (tables e-1 to e-12, doi.org/10.5061/dryad.60tv071). For each comparison, a new set of propensity scores was assessed based on the subsets of eligible patients. Positivity assumption was graphically evaluated (figures e-1 to e-12, doi. org/10.5061/dryad.60tv071). The outcomes were then modeled according to logistic regressions by using weighted likelihood maximization and robust variance estimator.

For time-to-event analysis, cause-specific Cox models were estimated by maximizing the partial weighted likelihood with a robust estimator for the variance. ${ }^{21}$ The adjusted survival curves were obtained using the weighted Kaplan-Meier estimator and compared using the adjusted log-rank test. ${ }^{22,23}$

All analyses were performed using the 3.3 .2 version of $\mathrm{R}$ software.

\section{Data availability}

Anonymized data can be made available upon reasonable request to the corresponding author.

\section{Results}

\section{Baseline characteristics: DMF is used in more active disease}

A total of 3,686 patients fulfilled the inclusion criteria, 713 treated with TRF and 1,057 with DMF (figure 1). The characteristics of the 1,916 nonincluded patients due to missing EDSS or MRI at baseline are reported in table e-13 (doi.org/ 10.5061/dryad.60tv071). When compared to the included patients, the main clinically relevant differences were a lower relapse rate 1 and 2 years prior to treatment initiation, an older age at treatment initiation, a longer disease duration, and a higher previous exposure to DMTs. These results indicate that the patients retained for analysis experienced more active disease than the others. However, it is worth noting that there was no difference in terms of percentage of nonincluded patients for both treatments (51.9\% for DMF and $51.9 \%$ for TRF).

Baseline demographic, clinical, and MRI characteristics of the 1,770 patients with RRMS included in the study are presented in table 1. Patients treated with DMF were younger with a shorter disease duration. In addition, there were more DMFthan TRF-treated patients with at least one relapse within a year or 2 preceding treatment initiation and at least one active lesion on baseline MRI scans. When considering only patients with relapse in each group in the year before initiating 
Table 1 List of variables taken into account for each outcome, in each propensity score model

\begin{tabular}{|c|c|c|c|c|c|c|c|c|}
\hline & $\begin{array}{l}\text { Age at } \\
\text { initiation }\end{array}$ & Sex & $\begin{array}{l}\text { Disease } \\
\text { duration }\end{array}$ & $\begin{array}{l}\text { Treatment-naive } \\
\text { vs treatment switch }\end{array}$ & $\begin{array}{l}\text { Center with } \\
>50 \text { included } \\
\text { patients }\end{array}$ & $\begin{array}{l}\text { EDSS } \\
\text { level }\end{array}$ & $\begin{array}{l}\text { Relapse within } \\
\text { the previous } \\
\text { year }\end{array}$ & $\begin{array}{l}\text { Gadolinium- } \\
\text { positive } \\
\text { enhancement }\end{array}$ \\
\hline \multicolumn{9}{|c|}{$\begin{array}{l}\text { At least one } \\
\text { relapse }\end{array}$} \\
\hline 1 year & $x$ & & $x$ & $x$ & $x$ & $x$ & $x$ & $x$ \\
\hline 2 year & $x$ & & $x$ & $x$ & & $x$ & $x$ & $x$ \\
\hline \multicolumn{9}{|c|}{ EDSS increase } \\
\hline 1 year & $x$ & $x$ & & & & $x$ & & \\
\hline 2 year & $x$ & $x$ & & $x$ & & $x$ & $x$ & \\
\hline \multicolumn{9}{|c|}{ New T2 lesions } \\
\hline 1 year & $x$ & & $x$ & $x$ & $x$ & & $x$ & $x$ \\
\hline 2 year & $x$ & & $x$ & $x$ & $x$ & & $x$ & $x$ \\
\hline \multicolumn{9}{|l|}{ NEDA } \\
\hline 1 year & $x$ & & $x$ & $x$ & $x$ & & $x$ & $x$ \\
\hline 2 year & & & & $x$ & $x$ & & $x$ & $x$ \\
\hline \multicolumn{9}{|c|}{$\begin{array}{l}\text { Withdrawal due } \\
\text { to inefficacy }\end{array}$} \\
\hline 1 year & $x$ & $x$ & $x$ & $x$ & $x$ & $x$ & $x$ & $x$ \\
\hline 2 year & $x$ & & $x$ & & & $x$ & $x$ & $x$ \\
\hline \multicolumn{9}{|c|}{$\begin{array}{l}\text { Withdrawal due } \\
\text { to adverse event }\end{array}$} \\
\hline 1 year & $x$ & $x$ & $x$ & $x$ & $x$ & $x$ & $x$ & $x$ \\
\hline 2 year & $x$ & $x$ & $x$ & & & $x$ & & $x$ \\
\hline
\end{tabular}

Abbreviations: EDSS = Expanded Disability Status Scale; NEDA = no evidence of disease activity.

the treatment, the number of relapses was 1.24 in the TRF group and 1.33 in the DMF group. These baseline comparisons suggest that patients treated with DMF experienced more clinically and radiologically active MS than patients treated with TRF. Of note, no difference was observed in terms of sex distribution or percentage of treatment-naive patients.

\section{Clinical outcomes: No difference between TRF- and DMF-treated patients}

The observed crude proportion of patients with at least one relapse at 1 year postinitiation was $19.4 \%(n=138)$ in the TRF group vs $21.6 \%(\mathrm{n}=230)$ in the DMF group $(p=$ $0.2214)$. This small difference was also observed at 2 years postinitiation: $28.1 \%(\mathrm{n}=200)$ in the TRF group vs $30.9 \%(\mathrm{n}$ $=327)$ in the DMF group $(p=0.1928)$. These first results may suggest that both treatments are efficient in controlling the risk of relapse after 1 and 2 years, seeing as a year prior to treatment initiation, the percentage of relapse was $48.5 \%$ in the TRF group and $60.1 \%$ in the DMF group.

However, the 2 groups are not directly comparable at baseline (table 1), probably due to indication biases. In order to compare these 2 groups, we performed an inverse probability weighting on propensity scores. The confounderadjusted percentage of patients with at least one relapse 1 year postinitiation was $21.6 \%$ (95\% confidence interval [CI] $18.5 \%-24.9 \%$ ) in the TRF group vs $20.2 \%$ (95\% CI $17.6 \%-22.6 \%)$ in the DMF group. The corresponding odds ratio (OR) for patients treated with DMF vs TRF was 0.92 (95\% CI $0.73 \%-1.16 \%$, figure 2 ). At 2 years, the results were similar as confounder-adjusted percentage of patients with at least one relapse was 30.4\% (95\% CI 26.9\%-33.9\%) in the TRF group vs $29.5 \%$ (95\% CI $26.6 \%-32.2 \%$ ) in the DMF group. The corresponding OR for patients treated with DMF vs TRF was 0.96 (95\% CI 0.78-1.19, figure 3), confirming a nonsignificant difference on effectiveness in terms of relapses.

When considering time to first relapse, as shown in figure 4 representing the confounder-adjusted survival curves, no statistically significant difference was observed between the 2 treatments $(p=0.7224$, adjusted log-rank test). The corresponding cause-specific hazard ratio of DMF vs TRF was 0.97 (95\% CI 0.81-1.16). 


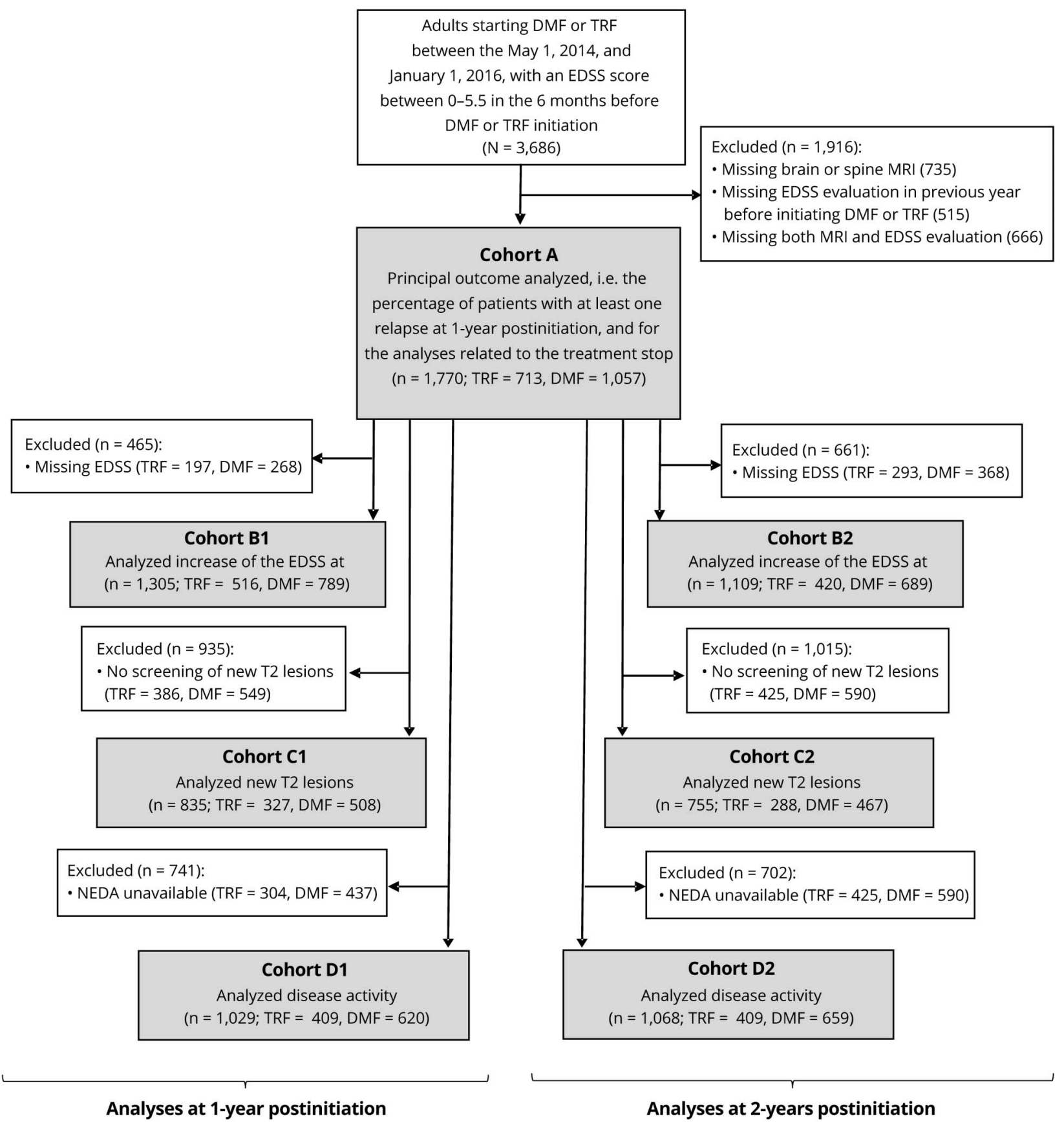

DMF = dimethyl fumarate; EDSS = Expanded Disability Status Scale; NEDA = no evidence of disease activity; TRF = teriflunomide.

This lack of difference between the 2 treatments at 1 and 2 years postinitiation was also observed for the proportion of EDSS increase. We selected the patients for whom an EDSS was available at $1(\mathrm{n}=1,305)$ or $2(\mathrm{n}=1,109)$ years postinitiation. When comparing included and excluded patients due to nonavailable EDSS, no significant difference was observed, except for the percentage of previously treated patients for the analysis after 2 years (tables e-14 and e-15, doi.org/10.5061/dryad.60tv071).

Among the 1,305 patients (cohort B1, figure 1), the observed crude percentage of patients with an increase in EDSS level was $27.3 \%$ in the TRF group vs $26.4 \%$ in the DMF group ( $p=$ $0.7007)$. The confounder-adjusted percentage was $27.4 \%$ (95\% CI $23.6 \%-31.4 \%$ ) in the TRF group vs $27.1 \%$ (95\% CI $24.1 \%-30.4 \%$ ) in the DMF group. The corresponding OR for patients treated with DMF vs TRF was 0.98 (95\% CI $0.77-1.27$, figure 2 ). The same results were found after 2 years of follow-up as the confounder-adjusted percentage of patients with an increase in the EDSS level was $41.6 \%$ (95\% CI $36.8 \%-46.6 \%)$ in the TRF group vs $40.6 \%$ (95\% CI $36.8 \%-44.2 \%)$ in the DMF group. The corresponding OR for patients treated with DMF vs TRF was 0.96 (95\% CI 


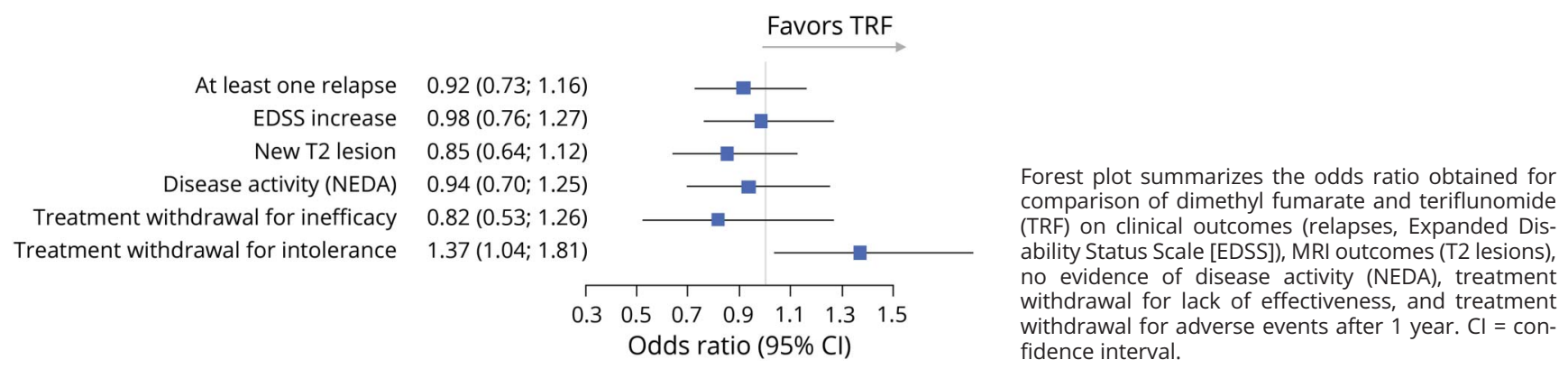

0.74-1.23, figure 3), confirming the absence of significant difference between the treatments.

\section{MRI-based outcomes: Better control of MRI activity with DMF at year 2}

Among the 1,770 patients of the main analysis, 935 patients were excluded because no MRI was performed at 1 year postinitiation. Compared to the 835 included patients, they had a longer disease duration, a higher exposure to previous DMTs, and a lower relapse rate within the year prior to initiation (table e-16, doi.org/10.5061/dryad.60tv071). This suggests, as expected, that patients with more active disease are more likely to have control MRIs after 1 or 2 years.

For this subgroup of 835 patients (cohort C1, figure 1), after weighting on the propensity scores, the confounder-adjusted percentage of patients with new T2 lesions was 46.9\% (95\% CI $41.3 \%-52.3 \%$ ) in the TRF group vs $42.9 \%$ (95\% CI $38.6 \%-47.1 \%)$ in the DMF group, showing a lack of significant difference (OR 0.85, 95\% CI 0.64\%-1.13\%, figure 2).

In the 2 years postinitiation, 1,015 patients were excluded because no MRI was performed and compared to the included patients (table e-17, doi.org/10.5061/dryad.60tv071), confirming more active disease in patients with a control MRI. The confounder-adjusted percentage of patients with new T2 lesions after 2 years was $72.2 \%$ (95\% CI 66.8\%-77.2\%) in the
TRF group vs $60.8 \%$ (95\% CI 56.3\%-65.3\%) in the DMF group, showing a significant effect of DMF reducing the risk of new T2 lesions (OR 0.60, 95\% CI 0.43-0.82, figure 3).

When comparing NEDA3 at 1 and 2 years postinitiation, similar results were found and explained by the difference observed in terms of risk of new T2 lesions after 2 years. After 1 year, the proportion of patients who reached NEDA3 was similar after weighting on the propensity scores (figure 2). After 2 years, the confounder-adjusted percentage of patients with active disease was $90.2 \%$ (95\% CI 87.2\%-92.9\%) in the TRF group vs $85.6 \%$ (95\% CI $82.9 \%-88.4 \%$ ) in the DMF group, confirming the previous results on MRI measures (OR 0.65, 95\% CI 0.43-0.95, figure 3).

\section{Reasons for treatment withdrawals were different between TRF and DMF}

The analyses were performed on cohort A (figure 1), composed of 1,057 patients treated with DMF and 713 with TRF. As shown in table 2, the rate of treatment discontinuation was different in patients treated with TRF or DMF at 6 months and 1 year but similar at 2 years. However, the reasons for withdrawal were different for each treatment. The confounder-adjusted percentage of patients who stopped their treatment because of inefficacy at 1 year postinitiation was $5.8 \%$ (95\% CI $4.0 \%-7.8 \%$ ) in the TRF group vs $4.8 \%$ (95\% CI 3.6\%-6.1\%) in the DMF group. The corresponding

Figure 3 Comparison of outcomes at 2 years

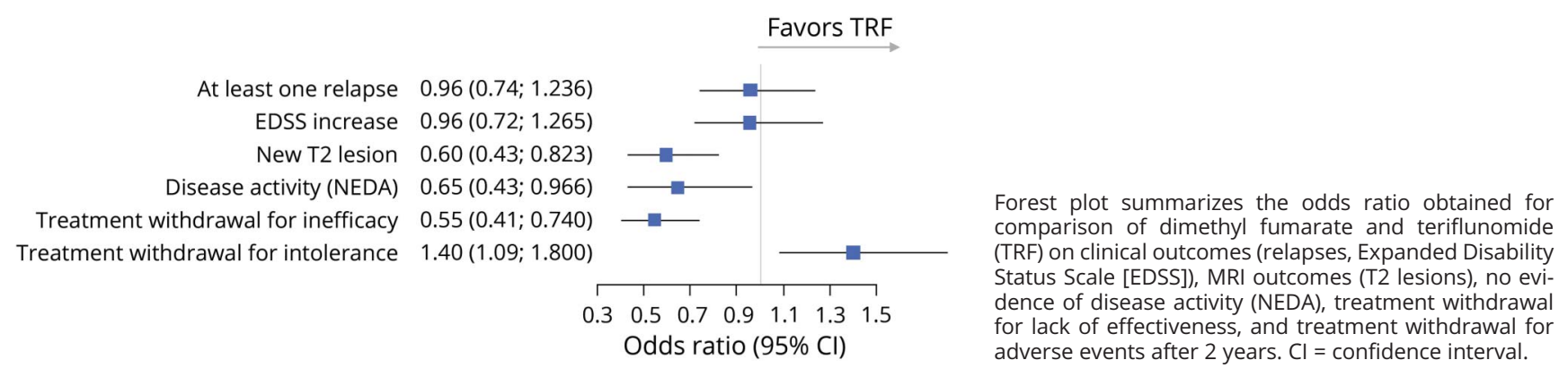


Figure 4 Time to first relapse in the 2 treatment groups

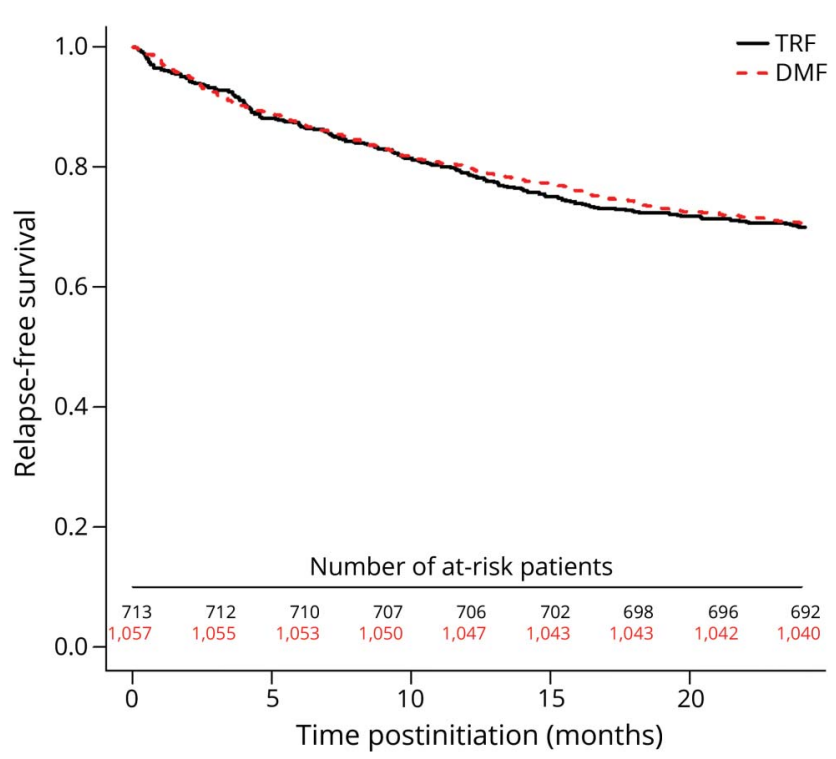

Confounder-adjusted survival curves of time to first relapse. The difference was not statistically significant ( $p=0.7224$, adjusted log-rank test). DMF = dimethyl fumarate; TRF = teriflunomide.

OR for patients treated with DMF vs TRF was 0.82 (95\% CI $0.53-1.28$, figure 2 ). Two years after treatment initiation, the confounder-adjusted percentage of patients who stopped their treatment due to inefficacy was $14.5 \%$ (95\% CI 11.9\%-17.3\%) in the TRF group vs $8.5 \%$ (95\% CI 7.0\%-10.2\%) in the DMF group, indicating a significantly lower percentage of patients stopping DMF after 2 years of treatment due to lack of effectiveness (OR 0.54, 95\% CI 0.41-0.74, figure 3).

We also analyzed treatment withdrawals due to the presence of adverse events, as reported by patients and neurologists. The confounder-adjusted percentage of patients who stopped their treatment because of intolerance or side effects at 1 year postinitiation was $12.7 \%$ (95\% CI $10.3 \%-15.2 \%)$ in the TRF group vs $16.6 \%$ (95\% CI $14.3 \%-18.9 \%$ ) in the DMF group, indicating that DMF was significantly less tolerated than TRF after 1 year (OR 1.37, 95\% CI 1.04-1.81, figure 2). Up to 2 years postinitiation, this difference remains significant. More precisely, the confounder-adjusted percentage of patients who stopped their treatment because of intolerance or side effects was $16.0 \%$ (95\% CI $13.4 \%-18.8 \%$ ) in the TRF group vs $21.0 \%$ (95\% CI 18.6\%-23.6\%) in the DMF group, with a corresponding OR of 1.39 (95\% CI 1.09-1.81, figure 3).

\section{Discussion}

With the increasing number of available drugs for preventing relapses and disability progression, and the lack of head-tohead randomized controlled trials (RCTs) comparing their efficacy, neurologists and patients need good quality observational studies to make more informed choices. In this study, we chose to compare TRF and DMF in real-life settings, in a cohort of French patients followed prospectively with a standardized collection of data. By using a propensity score-based methodology, we studied different outcomes at 1 and 2 years postinitiation: 2 were related to the clinical activity (relapse and disability progression), 1 was related to the activity observed on MRI (new T2 lesions), and 1 was a composite measure of disease activity (the NEDA3 score including relapses, disability progression, and new T2 lesion) and the reasons for treatment withdrawal (inefficacy or intolerance/adverse events). Clinical outcomes were not significantly different in DMF- vs TRF-treated patients. By contrast, we found fewer new T2 lesions for DMF than TRF at 2 years postinitiation, correlating with the greater percentage of patients reaching NEDA3 in DMF-treated patients. In agreement, we also reported more frequent treatment withdrawals due to lack of effectiveness after 2 years for patients under TRF. However, a consequence of this higher effectiveness of DMF was a higher rate of treatment withdrawal because of side effects.

Five other studies compared TRF and DMF. The first one was a network meta-analysis of RCTs of the different molecules used for $\mathrm{MS}^{8}$ while 2 others were based on a US claims database. $^{9,10}$ The last ones were based on observational databases from neurologists in Germany ${ }^{11}$ and Italy. ${ }^{12}$ In all these studies, save the Italian one, the authors reported on a superior efficacy of DMF over TRF in relapse prevention. However, it is difficult to compare our results with these studies. In Boster et al. ${ }^{9}$ and in Ontaneda et al., ${ }^{10}$ besides the fact that the characteristics of the US population differ from the French one, one can expect that their results were biased due to the lack of some confounders, such as the MRI data used to indicate TRF or DMF in clinical practice. Concerning the network meta-analysis from Hutchinson et al., ${ }^{8}$ the heterogeneity of the studies, as acknowledged by the authors, gives additional difficulties for the interpretation of the results. Moreover, this analysis is based on RCTs where the patients were highly selected and weakly representative of the population of patients with MS, as seen in real-life practice. ${ }^{24}$ The number of patients in the studies based on observational data $^{11,12}$ is lower than in our work, with a shorter follow-up, and they were not able to correct MS activity with MRI at baseline. Finally, they also used propensity matching for statistical analyses, which has proven limitations. ${ }^{23,25}$

The strength of our study is based on the high number of patients included in the main analysis $(n=1,057$ for DMF vs 713 for TRF). Moreover, we were able to take into account the MRI data both at baseline (as a confounding factor) and after 1 and 2 years (as an outcome in large subgroups). Indeed, as we previously reported in a similar study in MS comparing fingolimod to natalizumab, the MRI at baseline can be an important confounding factor. ${ }^{26}$ This is also the case in this study: the percentage of patients with gadolinium enhancement on baseline brain MRI was higher in patients treated with DMF than TRF, probably explaining part of the indication bias. 
Table 2 Characteristics of cohort A regarding analyses related to relapse, treatment discontinuation for inefficacy, treatment discontinuation for intolerance, and according to the treatment group

\begin{tabular}{|c|c|c|c|c|}
\hline & Overall $(n=1,770), n(\%)$ & TRF ( $\mathrm{n}=713), \mathrm{n}(\%)$ & DMF $(n=1,057), n(\%)$ & $p$ Value \\
\hline Patient age at MS onset, $y$, mean (SD) & $31.7(9.7)$ & $32.9(9.8)$ & $30.9(9.5)$ & $<0.0001$ \\
\hline Patient age at initiation, $y$, mean (SD) & $39.3(10.7)$ & $41.3(10.8)$ & $38.0(10.5)$ & $<0.0001$ \\
\hline Male recipient & $485(27.4)$ & $202(28.3)$ & $283(26.8)$ & 0.4713 \\
\hline Disease duration, $y$, mean (SD) & $7.6(7.4)$ & $8.4(7.8)$ & $7.1(7.0)$ & 0.0003 \\
\hline Disease-modifying therapy before initiation & $1,004(56.7)$ & $395(55.4)$ & $609(57.6)$ & 0.3560 \\
\hline Including interferon & & 237 & 369 & \\
\hline Glatiramer acetate & & 158 & 240 & \\
\hline EDSS level at initiation, mean (SD) & $1.7(1.3)$ & $1.7(1.3)$ & $1.7(1.2)$ & 0.9885 \\
\hline Patients with relapse within the year before initiation & $981(55.4)$ & $346(48.5)$ & $635(60.1)$ & $<0.0001$ \\
\hline Patients with relapse within the 2 years before initiation & $1,227(69.3)$ & $444(62.3)$ & $783(74.1)$ & $<0.0001$ \\
\hline No. of relapses in the previous year, mean (SD) & $0.72(0.77)$ & $0.60(0.73)$ & $0.80(0.80)$ & $<0.0001$ \\
\hline No. of relapses in the 2 previous years, mean (SD) & $1.03(0.96)$ & $0.88(0.90)$ & $1.14(0.98)$ & $<0.0001$ \\
\hline Gadolinium-positive lesion on MRI at baseline & $601(34.0)$ & $207(29.0)$ & $394(37.3)$ & 0.0003 \\
\hline Center with more than 50 included patients & $1,612(91.1)$ & $653(91.6)$ & $959(90.7)$ & 0.5354 \\
\hline At least one relapse at 1 year postinitiation ${ }^{a}$ & $368(20.8)$ & $138(19.4)$ & $230(21.6)$ & 0.2214 \\
\hline At least one relapse at 2 years postinitiation ${ }^{a}$ & $527(29.8)$ & $200(28.1)$ & $327(30.9)$ & 0.1928 \\
\hline Treatment discontinuation at 6 months ${ }^{a}$ & $287(16.2)$ & $98(13.7)$ & $189(17.9)$ & 0.0206 \\
\hline Treatment discontinuation at 1 year ${ }^{a}$ & $474(26.8)$ & $168(23.6)$ & $306(28.9)$ & 0.0121 \\
\hline 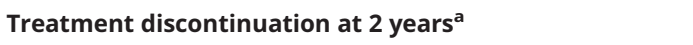 & $693(39.2)$ & $271(38.0)$ & $422(39.9)$ & 0.4180 \\
\hline
\end{tabular}

Abbreviations: DMF = dimethyl fumarate; EDSS = Expanded Disability Status Scale; MS = multiple sclerosis; TRF = teriflunomide

a Postinitiation characteristics.

Nevertheless, the main limitation of our study is the number of patients with missing values for EDSS and MRI. On this particular issue, we chose EDSS and MRI data as secondary outcomes, as there was no central readout and no central quality control for MRI and no ascertainment of irreversible EDSS score. For each outcome, we compared the characteristics of included and excluded patients at the time of the treatment initiation. The consequences were a reduction of the sample size and selection bias. Specifically, baseline MRI was more likely performed in patients with active disease. Similarly, missing MRI data at 1 and at 2 years postinitiation was not random and also depended on disease activity. Another drawback in our study is the impossibility to study additional outcomes such as the annualized relapse rate or the annualized rate of new T2 lesions. To our knowledge, no validated IPW method has been proposed and the data collected in our cohort do not allow to precisely compute the person-time. Furthermore, the choice of treatment may depend on measures other than the ones collected at baseline. Therefore, one cannot exclude possible confounders that were not taken into account. For example, smoking could be relevant information for treatment response that is not collected in the database. ${ }^{27}$ Finally, the follow-up was limited to 2 years postinitiation. A longer and more standardized follow-up would have been ideal to correctly perform time-toevent analyses and will be considered in future studies. Considering these weaknesses, interpretations of the results should be made with caution, particularly the lack of clinical difference observed between the 2 treatments after 1 and 2 years of use, which is probably restricted to the more active patients of the cohort and could not be extended to the whole cohort. The lack of statistical differences can be due to the reduced power of our study. Formal computation of the power is a methodologic issue when analyses are based on weighted propensity scores. However, we estimated the power equals $62 \%$, based on a comparable 1:1 RCT based on 713 patients per group, aiming to detect a $5 \%$ absolute difference between percentage of patients with at least one relapse 1 year postinitiation in the TRF vs the DMF group with a type I error rate at $5 \%$. We used a $5 \%$ threshold for the type I error rate, while we performed multiple comparisons. We did not correct this threshold, resulting in an increased risk to wrongly conclude a difference between the 2 treatments. Nevertheless, this risk is small considering the coherence of 
the comparison results. For instance, at 2 years postinitiation, one can see that (1) the 2 clinical endpoints are not statistically different and (2) the endpoint based on MRI results and the endpoint based on treatment withdrawal due to inefficacy are in favor of DMF. The overall coherence of these results decreases the risk of false-negative or -positive statistical differences.

Finally, our cohort-based study found no significant differences between TRF and DMF in terms of clinical activity of the disease, but a better control of MRI activity while on DMF after 2 years. This result must be interpreted with caution, as the possible higher effectiveness of DMF must be counterbalanced with the higher rate of treatment withdrawal due to intolerance. Results obtained from a future comparative RCT will be complementary to the strengths and limitations of this study based on real-life data.

\section{Acknowledgment}

The authors thank Sita Shah for English corrections.

\section{Study funding}

Supported by Fondation ARSEP, CHU Nantes (Appel d'Offre Interne), and Association ANTARES. The French Observatoire of Multiple Sclerosis is supported by a grant provided by the French State and handled by the Agence Nationale de la Recherche, within the framework of the Investments for the Future program, under the reference ANR-10-COHO-002. The study was supported by West Neurosciences Network and Société Francophone de Sclérose en Plaques, Fondation ARSEP, and by Appel d'Offre Interne du CHU de Nantes.

\section{Disclosure}

D. Laplaud has received consulting and lecturing fees, travel grants, and unconditional research support from Biogen, Genzyme, Novartis, Merck Serono, Roche, Sanofi Aventis, MedDay, and Teva Pharma. L. Barbin, R. Casey, and M. Debouverie report no disclosures relevant to the manuscript. J. De Sèze has received consulting and lecturing fees, travel grants, and unconditional research support from Biogen, Genzyme, Novartis, Merck Serono, Roche, Sanofi Aventis, and Teva Pharma. D. Brassat reports no disclosures relevant to the manuscript. S. Wiertlewski has received consulting and lecturing fees and travel grants from Biogen, Genzyme, Novartis, Merck Serono, Roche, Sanofi, and Teva Pharma. B. Brochet reports grants from French Ministry of Health, personal fees, and nonfinancial support from Biogen, grants from Merck, personal fees and nonfinancial support from Novartis, personal fees and nonfinancial support from Genzyme, grants, personal fees, and nonfinancial support from Teva, and grants and nonfinancial support from Bayer, outside the submitted work. J. Pelletier has received consulting and lecturing fees, travel grants, and unconditional research support from Biogen, Genzyme, Novartis, MedDay, Merck Serono, Roche, Sanofi Aventis, and Teva Pharma. P. Vermersch has received honoraria and consulting fees from Biogen, SanofiGenzyme, Novartis, Teva, and Merck. Gilles Edan has received consultancy and lecturing fees from Bayer-Schering, Biogen, LFB, Merck, Novartis, Roche, and Sanofi; research grants from Bayer, Biogen, Genzyme, Merck, Novartis, Roche, Teva, and the ARSEP Foundation; and has been principal investigator in phase 2 and 3 clinical studies conducted by Bayer, Biogen, Merck, Novartis, Sanofi-Aventis Teva, and 4 academic programs (Programmes Hospitaliers de Recherche Clinique) on MS sponsored by Rennes University Hospital. C. Lebrun-Frenay received fees for consulting or lectures from Biogen, Merck, MedDay, Roche, and Novartis. Pierre Clavelou received honoraria and traveling fees from Merck, Biogen, Roche, MedDay, Novartis, Genzyme, Teva, and Novartis. E. Thouvenot has received consulting and lecturing fees, travel grants, or unconditional research support from the following pharmaceutical companies: Actelion, Biogen, Genzyme, Merck Serono, Novartis, Roche, and Teva Pharma; has a patent pending for biomarkers of neurodegeneration and neuroregeneration; and received academic research support from PHRC and ARSEP Foundation. J. Camdessanché reports no disclosures relevant to the manuscript. A. Tourbah has received consulting and lecturing fees, travel grants, and research support from MedDay and Biogen. Bruno Stankoff has received consulting and lecturing fees and travel grants from Biogen Idec, Merck-Serono, Novartis, and Genzyme, and unconditional research support from Merck-Serono, Genzyme, and Roche. A. Al-Khedr and P. Cabre report no disclosures relevant to the manuscript. C. Lubetzki received fees for consultancy from Roche, Genzyme, Biogen, EMD-Serono, and Vertex; acted as PI (not coordinator) for trials (in MS) from Roche, Novartis, and Biogen; and received grants from EMD-Serono, Vertex, and Biogen. C. Papeix received conferences and consulting fees from Biogen, Merck, Novartis, Roche, and Sanofi-Genzyme. Eric Berger has received research support from Biogen and honoraria and consulting fees from Novartis, Sanofi Aventis, Biogen, Genzyme, Roche, and Teva Pharma. O. Heinzlef received consulting and lecturing fees from Bayer Schering, Merck, Teva, Genzyme, Novartis, Almirall, and Biogen; travel grants from Novartis, Teva, Genzyme, Merck Serono, and Biogen Idec; and research support from Roche, Merck, and Novartis. T. Debroucker has received fees as scientific adviser from Biogen and Novartis. T. Moreau has received fees as scientific adviser from Biogen, MedDay, Novartis, Genzyme, and Sanofi. O. Gout has received in the last year consulting and lecture fees, travel grants, and research support from Biogen Idec, Novartis, MedDay, Merck-Serono, Sanofi, and Teva Pharma. B. Bourre has served on a scientific advisory board for Biogen, Genzyme, Merck Serono, Novartis, and Roche and has received funding for travel and honoraria from Biogen Idec, Merck Serono, Novartis, Sanofi-Genzyme, Roche, and Teva. A. Wahab reports no disclosures relevant to the manuscript. P. Labauge has received consulting and lecturing fees, travel grants, and unconditional research support from Biogen, Genzyme, Novartis, Merck Serono, Roche, and Teva Pharma. L. Magy has received consulting, lecturing fees, or travel grants from Biogen, Novartis, Merck, Roche, Teva, MedDay, CSL Behring, LFB, Grifols, Alnylam, and Pharnext. G. Defer received 
personal compensation for a scientific advisory board from Biogen, Novartis, Genzyme, Merck-Serono, and Teva, and has received funding for travel and/or speaker honoraria from Merck Serono, Biogen, Sanofi-Genzyme, Novartis, and Teva. His institution received grants supporting research in his department from Merck Serono, Biogen, Genzyme, and Novartis. A. Guennoc received fees for consulting or lectures from Biogen, Merck, Sanofi-Genzyme, and Roche. N. Maubeuge reports no disclosures relevant to the manuscript. C. Labeyrie received consulting and lecturing fees from Biogen, Novartis, and Genzyme. I. Patry has received honoraria and consulting fees from Novartis, Genzyme, and Roche, research support from Biogen and Novartis, and travel grants from Genzyme, Novartis, and Roche. C. Nifle reports no disclosures relevant to the manuscript. $\mathrm{O}$. Casez has received honoraria or travel grants from Biogen, Merck, Novartis, Roche, and Genzyme. L. Michel received honoraria from Biogen, Merck Serono, Novartis Pharma, Sanofi Genzyme, and Roche. F. Rollot reports no disclosures relevant to the manuscript. E. Leray reports consulting and lecture fees or travel grants from Biogen, Genzyme, MedDay Pharmaceuticals, Merck, Novartis, and Roche. S. Vukusic has received grants, personal fees, and nonfinancial support from Biogen; grants and personal fees from Geneuro; grants, personal fees, and nonfinancial support from Genzyme; grants and personal fees from MedDay; grants, personal fees, and nonfinancial support from MerckSerono; grants, personal fees, and nonfinancial support from Novartis; grants, personal fees, and nonfinancial support from Roche; grants, personal fees, and nonfinancial support from Sanofi; and personal fees from Teva, outside the submitted work. Y. Foucher reports no disclosures relevant to the manuscript. Go to Neurology.org/N for full disclosures.

\section{Publication history}

Received by Neurology November 10, 2018. Accepted in final form April 10, 2019.

\section{Appendix 1 Authors}

\begin{tabular}{llll}
\hline Name & Location & Role & Contribution \\
\hline D.A. Laplaud & $\begin{array}{l}\text { Nantes, } \\
\text { France }\end{array}$ & Author & $\begin{array}{l}\text { Study design and } \\
\text { conception, acquisition and } \\
\text { interpretation of the data, } \\
\text { writing of the manuscript }\end{array}$ \\
\hline R. Casey & Lyon, France & Author & $\begin{array}{l}\text { Study design and } \\
\text { conception, data } \\
\text { management and } \\
\text { interpretation }\end{array}$ \\
\hline L. Barbin & Nantes, & Author & $\begin{array}{l}\text { Study conception and } \\
\text { writing of the manuscript }\end{array}$ \\
\hline M. Debouverie & $\begin{array}{l}\text { Nancy, } \\
\text { France }\end{array}$ & Author & $\begin{array}{l}\text { Acquisition and } \\
\text { interpretation of the data }\end{array}$ \\
\hline J. De Seze & Strasbourg, & Author & $\begin{array}{l}\text { Acquisition and } \\
\text { interpretation of the data }\end{array}$ \\
\hline Drance & Toulouse, & Author & $\begin{array}{l}\text { Acquisition and } \\
\text { interpretation of the data }\end{array}$ \\
\hline
\end{tabular}

Appendix 1 (continued)

\begin{tabular}{|c|c|c|c|}
\hline Name & Location & Role & Contribution \\
\hline S. Wiertlewski & $\begin{array}{l}\text { Nantes, } \\
\text { France }\end{array}$ & Author & $\begin{array}{l}\text { Acquisition and } \\
\text { interpretation of the data }\end{array}$ \\
\hline B. Brochet & $\begin{array}{l}\text { Bordeaux, } \\
\text { France }\end{array}$ & Author & $\begin{array}{l}\text { Acquisition and } \\
\text { interpretation of the data }\end{array}$ \\
\hline J. Pelletier & $\begin{array}{l}\text { Marseille, } \\
\text { France }\end{array}$ & Author & $\begin{array}{l}\text { Acquisition and } \\
\text { interpretation of the data }\end{array}$ \\
\hline P. Vermersch & Lille, France & Author & $\begin{array}{l}\text { Acquisition and } \\
\text { interpretation of the data }\end{array}$ \\
\hline G. Edan & $\begin{array}{l}\text { Rennes, } \\
\text { France }\end{array}$ & Author & $\begin{array}{l}\text { Acquisition and } \\
\text { interpretation of the data }\end{array}$ \\
\hline $\begin{array}{l}\text { C. Lebrun- } \\
\text { Frenay }\end{array}$ & Nice, France & Author & $\begin{array}{l}\text { Acquisition and } \\
\text { interpretation of the data }\end{array}$ \\
\hline P. Clavelou & $\begin{array}{l}\text { Clermont- } \\
\text { Ferrand, } \\
\text { France }\end{array}$ & Author & $\begin{array}{l}\text { Acquisition and } \\
\text { interpretation of the data }\end{array}$ \\
\hline E. Thouvenot & $\begin{array}{l}\text { Nîmes, } \\
\text { France }\end{array}$ & Author & $\begin{array}{l}\text { Acquisition and } \\
\text { interpretation of the data }\end{array}$ \\
\hline $\begin{array}{l}\text { J.P. } \\
\text { Camdessanche }\end{array}$ & $\begin{array}{l}\text { Saint- } \\
\text { Etienne, } \\
\text { France }\end{array}$ & Author & $\begin{array}{l}\text { Acquisition and } \\
\text { interpretation of the data }\end{array}$ \\
\hline A. Tourbah & $\begin{array}{l}\text { Reims, } \\
\text { France }\end{array}$ & Author & $\begin{array}{l}\text { Acquisition and } \\
\text { interpretation of the data }\end{array}$ \\
\hline B. Stankoff & Paris, France & Author & $\begin{array}{l}\text { Acquisition and } \\
\text { interpretation of the data }\end{array}$ \\
\hline A. Al Khedr & $\begin{array}{l}\text { Amiens, } \\
\text { France }\end{array}$ & Author & $\begin{array}{l}\text { Acquisition and } \\
\text { interpretation of the data }\end{array}$ \\
\hline P. Cabre & $\begin{array}{l}\text { Fort de } \\
\text { France, } \\
\text { France }\end{array}$ & Author & $\begin{array}{l}\text { Acquisition and } \\
\text { interpretation of the data }\end{array}$ \\
\hline C. Lubetzki & Paris, France & Author & $\begin{array}{l}\text { Acquisition and } \\
\text { interpretation of the data }\end{array}$ \\
\hline C. Papeux & Paris, France & Author & $\begin{array}{l}\text { Acquisition and } \\
\text { interpretation of the data }\end{array}$ \\
\hline E. Berger & $\begin{array}{l}\text { Besançon, } \\
\text { France }\end{array}$ & Author & $\begin{array}{l}\text { Acquisition and } \\
\text { interpretation of the data }\end{array}$ \\
\hline O. Heinzlef & $\begin{array}{l}\text { Poissy, } \\
\text { France }\end{array}$ & Author & $\begin{array}{l}\text { Acquisition and } \\
\text { interpretation of the data }\end{array}$ \\
\hline T. Debroucker & $\begin{array}{l}\text { Saint-Denis, } \\
\text { France }\end{array}$ & Author & $\begin{array}{l}\text { Acquisition and } \\
\text { interpretation of the data }\end{array}$ \\
\hline T. Moreau & $\begin{array}{l}\text { Dijon, } \\
\text { France }\end{array}$ & Author & $\begin{array}{l}\text { Acquisition and } \\
\text { interpretation of the data }\end{array}$ \\
\hline O. Gout & Paris, France & Author & $\begin{array}{l}\text { Acquisition and } \\
\text { interpretation of the data }\end{array}$ \\
\hline B. Bourre & $\begin{array}{l}\text { Rouen, } \\
\text { France }\end{array}$ & Author & $\begin{array}{l}\text { Acquisition and } \\
\text { interpretation of the data }\end{array}$ \\
\hline A. Wahab & $\begin{array}{l}\text { Créteil, } \\
\text { France }\end{array}$ & Author & $\begin{array}{l}\text { Acquisition and } \\
\text { interpretation of the data }\end{array}$ \\
\hline P. Labauge & $\begin{array}{l}\text { Montpellier, } \\
\text { France }\end{array}$ & Author & $\begin{array}{l}\text { Acquisition and } \\
\text { interpretation of the data }\end{array}$ \\
\hline L. Magy & $\begin{array}{l}\text { Limoges, } \\
\text { France }\end{array}$ & Author & $\begin{array}{l}\text { Acquisition and } \\
\text { interpretation of the data }\end{array}$ \\
\hline
\end{tabular}


Appendix 1 (continued)

\begin{tabular}{|c|c|c|c|}
\hline Name & Location & Role & Contribution \\
\hline G. Defer & $\begin{array}{l}\text { Caen, } \\
\text { France }\end{array}$ & Author & $\begin{array}{l}\text { Acquisition and } \\
\text { interpretation of the data }\end{array}$ \\
\hline A.M. Guennoc & $\begin{array}{l}\text { Tours, } \\
\text { France }\end{array}$ & Author & $\begin{array}{l}\text { Acquisition and } \\
\text { interpretation of the data }\end{array}$ \\
\hline N. Maubeuge & $\begin{array}{l}\text { Poitiers, } \\
\text { France }\end{array}$ & Author & $\begin{array}{l}\text { Acquisition and } \\
\text { interpretation of the data }\end{array}$ \\
\hline C. Labeyrie & Paris, France & Author & $\begin{array}{l}\text { Acquisition and } \\
\text { interpretation of the data }\end{array}$ \\
\hline I. Patry & $\begin{array}{l}\text { Corbeil, } \\
\text { France }\end{array}$ & Author & $\begin{array}{l}\text { Acquisition and } \\
\text { interpretation of the data }\end{array}$ \\
\hline C. Nifle & $\begin{array}{l}\text { Versailles, } \\
\text { France }\end{array}$ & Author & $\begin{array}{l}\text { Acquisition and } \\
\text { interpretation of the data }\end{array}$ \\
\hline O. Casez & $\begin{array}{l}\text { Grenoble, } \\
\text { France }\end{array}$ & Author & $\begin{array}{l}\text { Acquisition and } \\
\text { interpretation of the data }\end{array}$ \\
\hline L. Michel & $\begin{array}{l}\text { Rennes, } \\
\text { France }\end{array}$ & Author & $\begin{array}{l}\text { Acquisition and } \\
\text { interpretation of the data }\end{array}$ \\
\hline F. Rollot & Lyon, France & Author & $\begin{array}{l}\text { Study design and } \\
\text { conception }\end{array}$ \\
\hline E. Leray & $\begin{array}{l}\text { Rennes, } \\
\text { France }\end{array}$ & Author & $\begin{array}{l}\text { Study design and } \\
\text { conception }\end{array}$ \\
\hline S. Vukusic & Lyon, France & Author & $\begin{array}{l}\text { Study design and } \\
\text { conception, acquisition and } \\
\text { interpretation of the data, } \\
\text { important corrections on } \\
\text { the manuscript }\end{array}$ \\
\hline Y. Foucher & $\begin{array}{l}\text { Nantes, } \\
\text { France }\end{array}$ & Author & $\begin{array}{l}\text { Study design and } \\
\text { conception, interpretation } \\
\text { of the data, writing of the } \\
\text { manuscript }\end{array}$ \\
\hline
\end{tabular}

Appendix 2 Coinvestigators from OFSEP and SFSEP

\begin{tabular}{|c|c|c|c|}
\hline Name & Location & Role & Contribution \\
\hline B. Fontaine, MD, PhD & Paris & Investigator & $\begin{array}{l}\text { Data } \\
\text { acquisition }\end{array}$ \\
\hline R. Marignier, MD, PhD & Lyon & Investigator & $\begin{array}{l}\text { Data } \\
\text { acquisition }\end{array}$ \\
\hline F. Durand-Dubief, MD & Lyon & Investigator & $\begin{array}{l}\text { Data } \\
\text { acquisition }\end{array}$ \\
\hline G. Mathey, MD, PhD & Nancy & Investigator & $\begin{array}{l}\text { Data } \\
\text { acquisition }\end{array}$ \\
\hline E. Le Page, MD & Rennes & Investigator & $\begin{array}{l}\text { Data } \\
\text { acquisition }\end{array}$ \\
\hline $\begin{array}{l}\text { D. Peaureaux- } \\
\text { Averseng, MD }\end{array}$ & Bordeaux & Investigator & $\begin{array}{l}\text { Data } \\
\text { acquisition }\end{array}$ \\
\hline J.C. Ouallet, MD & Bordeaux & Investigator & $\begin{array}{l}\text { Data } \\
\text { acquisition }\end{array}$ \\
\hline A. Ruet, MD, PhD & Bordeaux & Investigator & $\begin{array}{l}\text { Data } \\
\text { acquisition }\end{array}$ \\
\hline $\begin{array}{l}\text { N. Collongues, MD, } \\
\text { PhD }\end{array}$ & Strasbourg & Investigator & $\begin{array}{l}\text { Data } \\
\text { acquisition }\end{array}$ \\
\hline
\end{tabular}

Appendix 2 (continued)

\begin{tabular}{|c|c|c|c|}
\hline Name & Location & Role & Contribution \\
\hline $\begin{array}{l}\text { P. Hautecoeur, MD, } \\
\text { PhD }\end{array}$ & Lille & Investigator & $\begin{array}{l}\text { Data } \\
\text { acquisition }\end{array}$ \\
\hline H. Zephir, MD, PhD & Lille & Investigator & $\begin{array}{l}\text { Data } \\
\text { acquisition }\end{array}$ \\
\hline E. Maillard, MD & Paris & Investigator & $\begin{array}{l}\text { Data } \\
\text { acquisition }\end{array}$ \\
\hline M. Cohen, MD & Nice & Investigator & $\begin{array}{l}\text { Data } \\
\text { acquisition }\end{array}$ \\
\hline N. Derache, MD & Caen & Investigator & $\begin{array}{l}\text { Data } \\
\text { acquisition }\end{array}$ \\
\hline P. Branger, MD & Caen & Investigator & $\begin{array}{l}\text { Data } \\
\text { acquisition }\end{array}$ \\
\hline X. Ayrignac, MD, PhD & Montpellier & Investigator & $\begin{array}{l}\text { Data } \\
\text { acquisition }\end{array}$ \\
\hline C. Carra-Dalliere, MD & Montpellier & Investigator & $\begin{array}{l}\text { Data } \\
\text { acquisition }\end{array}$ \\
\hline A. Fromont, MD, PhD & Dijon & Investigator & $\begin{array}{l}\text { Data } \\
\text { acquisition }\end{array}$ \\
\hline $\begin{array}{l}\text { L. Chamard- } \\
\text { Witkowski, MD }\end{array}$ & Besançon & Investigator & $\begin{array}{l}\text { Data } \\
\text { acquisition }\end{array}$ \\
\hline F. Taithe, MD, PhD & $\begin{array}{l}\text { Clermont- } \\
\text { Ferrand }\end{array}$ & Investigator & $\begin{array}{l}\text { Data } \\
\text { acquisition }\end{array}$ \\
\hline X. Moisset, MD & $\begin{array}{l}\text { Clermont- } \\
\text { Ferrand }\end{array}$ & Investigator & $\begin{array}{l}\text { Data } \\
\text { acquisition }\end{array}$ \\
\hline B. Audoin, MD, PhD & Marseille & Investigator & $\begin{array}{l}\text { Data } \\
\text { acquisition }\end{array}$ \\
\hline A. Rico-Lamy, MD & Marseille & Investigator & $\begin{array}{l}\text { Data } \\
\text { acquisition }\end{array}$ \\
\hline G. Castelnovo, MD & Nîmes & Investigator & $\begin{array}{l}\text { Data } \\
\text { acquisition }\end{array}$ \\
\hline C. Giannesini, MD & Paris & Investigator & $\begin{array}{l}\text { Data } \\
\text { acquisition }\end{array}$ \\
\hline O. Fagniez, MD & Poissy & Investigator & $\begin{array}{l}\text { Data } \\
\text { acquisition }\end{array}$ \\
\hline C. Bensa, MD & Paris & Investigator & $\begin{array}{l}\text { Data } \\
\text { acquisition }\end{array}$ \\
\hline A. Gueguen, MD & Paris & Investigator & $\begin{array}{l}\text { Data } \\
\text { acquisition }\end{array}$ \\
\hline $\begin{array}{l}\text { I. Tabellah Kasonde, } \\
\text { MD }\end{array}$ & $\begin{array}{l}\text { Fort-de- } \\
\text { France }\end{array}$ & Investigator & $\begin{array}{l}\text { Data } \\
\text { acquisition }\end{array}$ \\
\hline A. De Vilmarest, MD & $\begin{array}{l}\text { Fort-de- } \\
\text { France }\end{array}$ & Investigator & $\begin{array}{l}\text { Data } \\
\text { acquisition }\end{array}$ \\
\hline A. Montcuquet, MD & Limoges & Investigator & $\begin{array}{l}\text { Data } \\
\text { acquisition }\end{array}$ \\
\hline M. Vaillants, MD & Grenoble & Investigator & $\begin{array}{l}\text { Data } \\
\text { acquisition }\end{array}$ \\
\hline S. Beltran, MD & Tours & Investigator & $\begin{array}{l}\text { Data } \\
\text { acquisition }\end{array}$ \\
\hline A. Creange, MD & Créteil & Investigator & $\begin{array}{l}\text { Data } \\
\text { acquisition }\end{array}$ \\
\hline
\end{tabular}


Appendix 2 (continued)

\begin{tabular}{|c|c|c|c|}
\hline Name & Location & Role & Contribution \\
\hline S. Ayache, MD & Créteil & Investigator & $\begin{array}{l}\text { Data } \\
\text { acquisition }\end{array}$ \\
\hline M. Abdellaoui, MD & Créteil & Investigator & $\begin{array}{l}\text { Data } \\
\text { acquisition }\end{array}$ \\
\hline C. Pottier, MD & Paris & Investigator & $\begin{array}{l}\text { Data } \\
\text { acquisition }\end{array}$ \\
\hline I. Slesari, MD & Paris & Investigator & $\begin{array}{l}\text { Data } \\
\text { acquisition }\end{array}$ \\
\hline V. Deburghraeve, MD & Rennes & Investigator & $\begin{array}{l}\text { Data } \\
\text { acquisition }\end{array}$ \\
\hline J.P. Neau, MD & Poitiers & Investigator & $\begin{array}{l}\text { Data } \\
\text { acquisition }\end{array}$ \\
\hline J. Servan, MD & Versailles & Investigator & $\begin{array}{l}\text { Data } \\
\text { acquisition }\end{array}$ \\
\hline F. Pico, MD & Versailles & Investigator & $\begin{array}{l}\text { Data } \\
\text { acquisition }\end{array}$ \\
\hline C. Henry, MD & Saint-Denis & Investigator & $\begin{array}{l}\text { Data } \\
\text { acquisition }\end{array}$ \\
\hline K. Hankiewicz, MD & Saint-Denis & Investigator & $\begin{array}{l}\text { Data } \\
\text { acquisition }\end{array}$ \\
\hline
\end{tabular}

\section{References}

1. O'Connor PW, Li D, Freedman MS, et al. A phase II study of the safety and efficacy of teriflunomide in multiple sclerosis with relapses. Neurology 2006;66:894-900.

2. Confavreux C, Li DK, Freedman MS, et al. Long-term follow-up of a phase 2 study of oral teriflunomide in relapsing multiple sclerosis: safety and efficacy results up to 8.5 years. Mult Scler 2012;18:1278-1289.

3. O'Connor P, Wolinsky JS, Confavreux C, et al. Randomized trial of oral teriflunomide for relapsing multiple sclerosis. N Engl J Med 2011;365:1293-1303.

4. Confavreux C, O'Connor P, Comi G, et al. Oral teriflunomide for patients with relapsing multiple sclerosis (TOWER): a randomised, double-blind, placebocontrolled, phase 3 trial. Lancet Neurol 2014;13:247-256.

5. Kappos L, Gold R, Miller DH, et al. Efficacy and safety of oral fumarate in patients with relapsing-remitting multiple sclerosis: a multicentre, randomised, double-blind, placebo-controlled phase IIb study. Lancet 2008;372:1463-1472.

6. Gold R, Kappos L, Arnold DL, et al. Placebo-controlled phase 3 study of oral BG-12 for relapsing multiple sclerosis. N Engl J Med 2012;367:1098-1107.

7. Fox RJ, Miller DH, Phillips JT, et al. Placebo-controlled phase 3 study of oral BG-12 or glatiramer in multiple sclerosis. N Engl J Med 2012;367:1087-1097.
8. Hutchinson M, Fox RJ, Havrdova E, et al. Efficacy and safety of BG-12 (dimethyl fumarate) and other disease-modifying therapies for the treatment of relapsingremitting multiple sclerosis: a systematic review and mixed treatment comparison. Curr Med Res Opin 2014;30:613-627.

9. Boster A, Nicholas J, Wu N, et al. Comparative effectiveness research of diseasemodifying therapies for the management of multiple sclerosis: analysis of a large Health insurance claims database. Neurol Ther 2017;6:91-102.

10. Ontaneda D, Nicholas J, Carraro M, et al. Comparative effectiveness of dimethyl fumarate versus fingolimod and teriflunomide among MS patients switching from first-generation platform therapies in the US. Mult Scler Relat Disord 2019;27: 101-111.

11. Braune S, Grimm S, van Hövell P, et al; NTD Study Group. Comparative effectivenes of delayed-release dimethyl fumarate versus interferon, glatiramer acetate, teriflunomide, or fingolimod: results from the German NeuroTransData registry. J Neurol 2018;265:2980-2992.

12. D'Amico E, Zanghì A, Callari G, et al. Comparable efficacy and safety of dimethyl fumarate and teriflunomide treatment in relapsing-remitting multiple sclerosis: an Italian real-word multicenter experience. Ther Adv Neurol Disord 2018;11: 1756286418796404

13. Confavreux C, Compston DA, Hommes OR, McDonald WI, Thompson AJ. EDMUS, a European database for multiple sclerosis. J Neurol Neurosurg Psychiatry 1992;55: 671-676.

14. Polman CH, Reingold SC, Banwell B, et al. Diagnostic criteria for multiple sclerosis: 2010 revisions to the McDonald criteria. Ann Neurol 2011;69:292-302.

15. Rotstein DL, Healy BC, Malik MT, Chitnis T, Weiner HL. Evaluation of no evidence of disease activity in a 7-year longitudinal multiple sclerosis cohort. JAMA Neurol 2015;72:152-158.

16. Cole SR, Hernán MA. Constructing inverse probability weights for marginal structural models. Am J Epidemiol 2008;168:656-664.

17. Ali MS, Groenwold RHH, Belitser SV, et al. Reporting of covariate selection and balance assessment in propensity score analysis is suboptimal: a systematic review. J Clin Epidemiol 2015;68:112-121.

18. Austin PC. An introduction to propensity score methods for reducing the effects of confounding in observational studies. Multivariate Behav Res 2011;46:399-424.

19. Brookhart MA, Schneeweiss S, Rothman KJ, Glynn RJ, Avorn J, Stürmer T. Variable selection for propensity score models. Am J Epidemiol 2006;163:1149-1156.

20. Myers JA, Rassen JA, Gagne JJ, et al. Effects of adjusting for instrumental variables on bias and precision of effect estimates. Am J Epidemiol 2011;174:1213-1222.

21. Lin DY, Wei LJ. The robust inference for the Cox proportional hazards model. J Am Stat Assoc 1989;84:1074-1078.

22. Xie J, Liu C. Adjusted Kaplan-Meier estimator and log-rank test with inverse probability of treatment weighting for survival data. Stat Med 2005;24:3089-3110.

23. Le Borgne F, Giraudeau B, Querard AH, Giral M, Foucher Y. Comparisons of the performance of different statistical tests for time-to-event analysis with confounding factors: practical illustrations in kidney transplantation. Stat Med 2016;35: 1103-1116.

24. Zwarenstein M, Treweek S. What kind of randomized trials do we need? CMAJ 2009 180:998-1000.

25. Gayat E, Resche-Rigon M, Mary JY, Porcher R. Propensity score applied to survival data analysis through proportional hazards models: a Monte Carlo study. Pharm Stat 2012;11:222-229.

26. Barbin L, Rousseau C, Jousset N, et al. Comparative efficacy of fingolimod vs natalizumab: a French multicenter observational study. Neurology 2016;86: 771-778.

27. Petersen ER, Oturai AB, Koch-Henriksen N, et al. Smoking affects the interferon beta treatment response in multiple sclerosis. Neurology 2018;90:e593-e600. 


\section{Neurology}

Comparative effectiveness of teriflunomide vs dimethyl fumarate in multiple sclerosis

David-Axel Laplaud, Romain Casey, Laetitia Barbin, et al.

Neurology 2019;93;e635-e646 Published Online before print July 12, 2019

DOI 10.1212/WNL.0000000000007938

This information is current as of July 12, 2019

Updated Information \&
Services

References

Citations

Subspecialty Collections

Permissions \& Licensing

Reprints including high resolution figures, can be found at: http://n.neurology.org/content/93/7/e635.full

This article cites 27 articles, 5 of which you can access for free at: http://n.neurology.org/content/93/7/e635.full\#ref-list-1

This article has been cited by 1 HighWire-hosted articles: http://n.neurology.org/content/93/7/e635.full\#\#otherarticles

This article, along with others on similar topics, appears in the following collection(s):

\section{Class III}

http://n.neurology.org/cgi/collection/class_iii

Clinical trials Observational study (Cohort, Case control)

http://n.neurology.org/cgi/collection/clinical_trials_observational_stud y_cohort_case_control

Multiple sclerosis

http://n.neurology.org/cgi/collection/multiple_sclerosis

Information about reproducing this article in parts (figures,tables) or in its entirety can be found online at:

http://www.neurology.org/about/about_the_journal\#permissions

Information about ordering reprints can be found online:

http://n.neurology.org/subscribers/advertise

Neurology ${ }^{\circledR}$ is the official journal of the American Academy of Neurology. Published continuously since 1951, it is now a weekly with 48 issues per year. Copyright Copyright (C) 2019 The Author(s). Published by Wolters Kluwer Health, Inc. on behalf of the American Academy of Neurology.. All rights reserved. Print ISSN: 0028-3878. Online ISSN: 1526-632X.

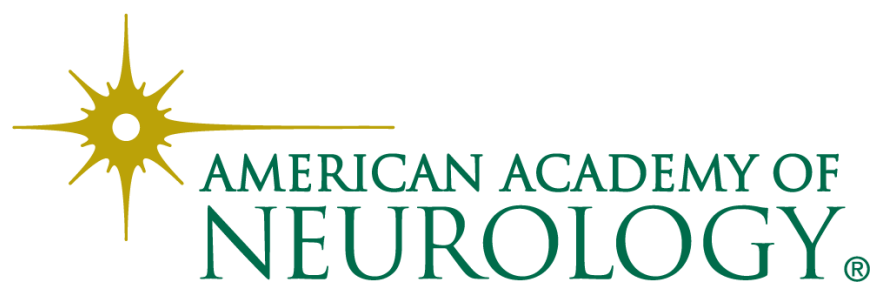

